\title{
Az idegenek szemlélete a japán közösségi érintkezések tükrében
}

\section{Bevezetés}

A globalizálódó világban a japánok egyre többször találják szembe magukat más etnikumhoz, eltérő kultúrához tartozó emberekkel, csakhogy a találkozás kezdeti örömeit gyakran beárnyékolják a nyelvi és kulturális nehézségek okozta problémák, amelyek könnyen gátat vetnek a további kommunikációnak. Habár a világ bármely más pontján is adódhatnak hasonló gondok, a japán társadalom különösen zárt rendszer, ahol a nyelvi korlátoktól függetlenül is nehezen nyitnak az odalátogató idegenek vagy a saját köreikbe nem tartozó honfitársaik irányába. ${ }^{1}$ Az emberiség történelmében már az ősi időktől fogva létezett az az igény, hogy az adott közösség számára ismeretlen elemeket valamilyen formában megkülönböztessék a közösséget alkotó tagoktól. Ez a megbélyegzés biztosította a csoport fennmaradását, ezért szélsőségesebb esetekben kirekesztéssel éltek, és elhatárolták magukat mindenkitől, aki gondot jelenthetett a saját társadalmukra nézve. ${ }^{2}$

Nem meglepó, hogy a fokozódó globalizációnak köszönhetóen már a 20. század első felétől többféle tudományág - a néprajz, a szociológia és a pszichológia - is átfogóan tanulmányozta az idegenekkel szemben mutatott emberi viselkedés különféle formáit. Többek között Robert E. Park (1864-1944) szociológus munkássága nyomán került központba a téma, aki a máshonnan érkezettek bizonytalan társadalmi státuszára utalva ${ }^{3}$ bevezette a marginal man, azaz „határ menti személy” terminológiáját, ${ }^{4}$ de kiemelhetjük

Ishii 2001: 145-146.

Akamatsu 2005: 15.

A bizonytalan státusz abból adódik, hogy az idegen saját közösségétől eltávolodott, miközben nem teljes körú tagja annak a csoportnak, ahová elérkezett.

4 Park 1928: 881-893. 
még Georg Simmel (1858-1918) német szociológus nevét is, aki elsóként fejtette ki tudományos nézeteit az európai típusú idegen-elmélettel (ijin-ron 異人論) kapcsolatban. ${ }^{5}$ Japán oldalról is adódtak jelentős munkásságot folytató szociológusok, akik nem csupán a szociológia, hanem a folklór, irodalom, történelem és vallástudomány szemszögéből próbálták vizsgálni a specifikusan japán idegen-szemléletet. Ilyen volt Orikuchi Shinobu 折口信夫 (1887-1953) néprajzkutató is, aki bevezette a nyugati típusú marginal man japán nyelvú ősi megfelelőjét, a marebitót 稀人 , valamint nyomon követte a kifejezés fogalmi változásait az egyes japán nyelvú források alapján. ${ }^{6}$

Jelen dolgozat célja a japán közösségbe nem tartozó „határ menti idegenek" alakjának bemutatásán kívül az ismeretlenek felé irányuló közösségi érintkezéseknek, valamint - a legfontosabb szociokulturális fogalmakon keresztuil - a japán társadalomban múködő sokrétû emberi kapcsolatok világának a megragadása.

\section{A japán típusú marginal man, azaz a marebito alakja}

Már az őskortól fogva létezhetett a marebito vagy az ősi japán nyelvben használt marōdo kifejezés, amely messzi földről jött, „ritka vendéget” jelentett, aki alkalomadtán elvetődött az elzárt japán közösségekhez. Orikuchi kimutatta, hogy legkorábban a Nara-korban (710-784) bukkant fel a marebitót jelölő írásjegy, amely jelentését tekintve igencsak pozitív volt: olyan isteni személyt jelölt, aki boldogságot és jó szerencsét hoz a közösség életébe.? A későbbiekben valamelyest változott ez a képzet: nem istenségek, hanem a tengeren túl húzódó túlvilágról, Tokoyóból 常世 visszalátogató ősök szellemeinek képében jelentek meg a marebitók, akik segítették vagy éppen megbüntették saját leszármazottaikat. Az idők folyamán pedig a faluról falura vándorló idősebb embereket, szerzeteseket, jósokat vagy hokaibitókat ほかい人8

\footnotetext{
Simmel 1950: 402-408.

Ishii 2001: 146.

Ishii 2001: 149.

8 Vándor koldus, aki a legendák szerint a falvakban házról házra járó, az istenek szavait hirdető és jó szerencsét hozó előadómúvészek leszármazottja.
} 
illették ezzel a kifejezéssel, akikről úgy vélték, hogy természetfeletti erőkkel bírnak. Köszönhetôen annak az újszerú technikai tudásnak és az ismeretlen világgal kapcsolatos információnak, amelyet magukkal hordoztak, a messzi hegyvidéki falvak közösségei pozitív fogadtatásban részesítették őket.

A japán középkor (1185-1602) során a marebitók elvesztették természetfeletti képességeiket, így nem csak pozitív képzet társult hozzájuk: hol szívélyesen, hol pedig barátságtalanul fogadták őket - ez utóbbi esetben szerencsétlenséget hozó démonként (oni 鬼) vagy szörnyként (yōkai 妖怪) tekintettek rájuk. Ilyen formán a marebitók ambivalens megítélése továbbhagyományozódott a későbbiekben született újabb kifejezés, az ijinek 異人, azaz a marebito fogalmának pszichoszemantikus kiterjesztésével létrejött idegenek, valamint a tengeren túlról érkezett, „külhoni” gaijinek 外人 alakjában is. ${ }^{9}$

Nem meglepő, hogy a marebito ósi fogalmát és az újszerú ijin kifejezést egymás helyett is használták, majd a kora újkor során (1603-1867) kezdték el az utóbbit szélesebb körben alkalmazni a faluhatár közelében felbukkanó valódi hús-vér emberekre. ${ }^{10}$ Habár az újkori Japánban megindult belső népmozgás hatására egyre több ijin vetôdött el az elzárt településekre, az ottani közösségek szemében legtöbbjuik megbélyegzett volt, hiszen a Tokugawa sógunátus idején (1603-1867) megalakult négy társadalmi kaszt közül (szamurájok, parasztok, kézmúvesek, kereskedők) egyikhez sem tartoztak. Így ezek a számkivetettek teljes kívüiállóként, a határ menti hegyek és folyók környékén telepedhettek csak le. ${ }^{11}$ Számos bizonyítékot találhatunk minderre az elzárt japán falusi közösségek kozmológiájában, amely szerint az idegenek, akik kinézetükben és nyelvhasználatukban is elütöttek az őslakosoktól, könnyen felboríthatták a társadalmi rendet, és romlásba dönthették a világot. Mivel a jól ismert, múködő rend keretein kívülról érkeztek, nagy befolyással bírtak a falu életére: úgy tartották róluk, hogy rejtélyes erókkel bírnak, amelyek romlást hozhatnak a településre, ezért személyüket gyakran tabu tárgyává tették. ${ }^{12}$

\footnotetext{
Miyata 1986: 1.

10 Komatsu 1995: 172.

11 Miyamoto 1969: 13-15.

12 Akasaka 1992: 85.
} 
Legtöbb esetben ez az elhatárolódási szándék különféle rituálék végzésével is párosult, hiszen szükségesnek tartották, hogy az idegenek erejét semlegesítsék a falu határában, akik csak ezután jöhettek beljebb, és vehették fel a kapcsolatot az ott élőkkel. Nem meglepő módon az idegenekhez erósen kötődött a tisztátalanság ${ }^{13}$ (kegare 穢れ) képzete is. ${ }^{14}$ A lakóközösség számára ismeretlen világ ugyanis eredendően tisztátalan, veszélyes térnek (kegare no kūkan ケガレの空 間) minősült, amelynek ártalmaitól a falusi rítusok védték meg az ott élóket. ${ }^{15}$

A hagyományos népi világlátás szerint a kozmosz középpontjában a saját lakóközösség állt, amely mint egy mikrokozmosz létezett, szemben az ismeretlen, ambivalens megítélésú külvilággal. ${ }^{16}$ Mindaz, ami a külvilágból származott, nem juthatott be a faluba, csupán annak a határát közelíthette meg. Azoknak a személyeknek, akik letelepedési céllal érkeztek egy másik közegből, több évig tartó, többfokozatú rituálén kellett átesniük, amit murairinek 村入り nevezünk. A murairi átmeneti rítusához a falu teljes egészének a jóváhagyása volt szükséges. A megfelelő purifikációs rituálék után a falu elöljárója mutatta be a leendő tagot a közösségnek, akinek ki kellett vennie a részét a közmunkából is - ha a közösség érdeke úgy kívánta, akkor a közutakat tisztította. Egyenrangú falusi taggá az ujiko $i r i^{17}$ 氏子入り után válhatott, amikor azonos jogokat és kötelezettségeket kapott. ${ }^{18}$ Végül a kabu irit 株入り követôen - amikor már saját háztartását vezette - vehetett részt a közösségi rítusokban, ekkorra ugyanis már a közösség elismert tagjaként nem tekintettek rá kívülállóként. ${ }^{19}$

13 A japán népi sintó hiedelemvilágában a lelki értelemben vett tisztátalanság állapotát számos tényezô válthatja ki. Ilyen az elhunyt személlyel és annak családjával, a betegekkel való érintkezés, de hasonló a vérrel kapcsolatos testi jelenségektől (pl. szülés) való félelem is. Minden tisztátalannak bélyegzett esemény nemcsak az egyén, hanem a közösség életére is negatívan hathatott ki, ezért volt szüikség a tisztító célzatú rituálék elvégzésére. A tisztátalanság kérdéskörének gazdag szakirodalma van: japán részról jelentős Namihira Emiko Kegare címú munkája, de kiemelhetjük Mary Douglas Purity and Danger - An Analysis of the Concepts of Pollution and Taboo címú könyvét is.

14 Akasaka 1992: 87.

15 Namihira 2009: 209.

16 Akasaka 1992: 285.

17 Az ujiko iri rítusa során a falut védelmező entitás, az uji gami 氏神 védelme alá helyezték a közösség új tagját, aki ezért cserébe szertartásos keretek között éltette és szolgálta ôt a helyi sintó szentélyben.

18 Az ujiko iri témája kapcsán magyar nyelven is olvasható szakirodalom, például Papp 2013.

19 Akasaka 1992: 287. 


\section{A marginalitás további megnyilvánulási formái a japán társadalomban}

Az ijin, tehát az idegenre vonatkoztatott kifejezés a 20. század második felére azonban a „váratlan látogató” fogalmához képest sokrétúbb és színesebb jelentésűvé nőtte ki magát, ami a mai japán nyelvben is megfigyelhető.A japán értelmező kéziszótár szerint például az ijin lehet különleges képességû vagy kinézetű személy, vagy egy, a közösséghez nem tartozó, „,másik” személy, esetleg egy idegen országból származó ember (gaijin vagy gaikoku-jin 外国人). ${ }^{20}$ Az ijin szó további jelentésbővítése a kulturális antropológiával és néprajzzal foglalkozó tudósoknak köszönhető, akik a kutatásaik során az az ijint nem csupán valódi személyként, hanem természetfeletti lényként, démonként kezelték. Végül az ijin sokrétú fogalmán keresztuil vezetett az út a modern kifejezésû ,külföldi személy”, azaz a gaijin vagy gaikoku-jin kifejezések irányába, amelyeket egymás szinonimájaként is használhatnak, bár manapság a média és a hétköznapi nyelv szintjén a gaijin kifejezés fordul elő gyakrabban. ${ }^{21}$ A gaijin terminust a Japán partjainál felbukkant nyugatiakkal (nanban-jin 南蚠人) szemben alkalmazhatták először a Tokugawa sógunátus idején, akikkel szemben nagyfokú bizalmatlanságot mutattak.

A gaijin szó a hivatalosabb hangvételú gaikoku-jin rövidített formáját jelöli, bár a kettő között is lehet egy árnyalatnyi jelentésbeli különbség, hiszen a gaijin, azaz ,kívülálló” értelemben olyan külföldi állampolgárt jelent, aki állandó letelepedési engedéllyel rendelkezik az országban, míg a gaikoku-jin esetében olyan ,külföldiről” van szó, akinek nincs japán állampolgársága. ${ }^{22} \mathrm{~A}$ japán társadalom mélyén él még az elképzelés, amelyben az országot egy kiterjedt faluként fogják fel, ahol ők az őslakosok, akik az odaérkező idegenektől ösztönösen megkülönböztetik magukat. Emiatt a külföldről jött idegenekkel szemben mindmáig ambivalens érzelmeket táplálnak: egyfelől az ország fejlődését elősegítő civilizáció képviselőit tisztelik bennük, de akadnak olyanok is, akik ösztönösen elha-

20 Nippon Kokugo Daijiten 9. 1987: 750.

21 Ishii 2001: 151.

22 Perkins 1991: 100. 
tárolják tőlük magukat. ${ }^{23}$

Akár a marebito, az ijin vagy a gaijin fogalmáról legyen is szó, mindegyiket a marginalitás és a megkülönböztetés jegyében használják, tehát egyfajta általános elóítélet mutatkozik meg bennük. ${ }^{24}$ Létezik azonban egy speciális kategória a marginalitásban élók között. Habár a japán társadalomban élik mindennapjaikat, japán nemzetiségúek, mégis megbélyegzettnek minősülnek.Ilyenek anemzetközi házasságból született japánok, akik tehát csupán félig japán származásúak, és akiket ainoko 合の子 néven illettek az 1970-es évektől, de manapság csak a hāfu ハーフ, azaz a „,élig japán” kifejezést használják rájuk. Habár kinézetükben hasonlítanak a japánokra, családi és kulturális hátterük tekintetében viszont különböznek, ezért a közösség és a társadalom egészére nézve potenciális veszély forrásai lehetnek. ${ }^{25}$ Sőt némelyekre nem tehetséges, nyelveket beszéló személyként, hanem sokkal inkább tökéletlen japánként tekintenek. ${ }^{26} \mathrm{Nem}$ meglepő tehát, hogy az ilyen típusú, társadalmilag bizonytalan státuszú elemeket sokkal látványosabban rekesztik ki a közösségbőll, és bélyegzik meg, mint a teljesen kívülálló külföldieket. ${ }^{27}$ Manapság azonban fokozatosan enyhülni látszik ez a felfogás, így a félig japán származásúaknak is több lehetőségük van érvényesülni az egyre befogadóbbá váló ázsiai társadalomban.

\section{Uchi-soto és marginalitás a japán emberi kapcsolatok világában}

A mindennapi társadalmi érintkezés meghatározó fogalompárja a kint (soto 外) és a bent ( $u c h i$ 内), amelyek az emberi kapcsolatok közvetlenségére vagy azok hiányára utalnak. Az emberi kapcsolatok kinti, avagy külső körébe

23 Japán egységes, kiterjedt faluként való interpretálása Katō Shūichi 加藤周一 nevéhez köthető, aki a Nippon 日本 címú tanulmányában fejti ki nézeteit. Elméletét Ishii foglalja össze (Ishii 2001: 152).

24 Ishii 2001: 152.

25 Hamabata 1986: 369.

26 Hamabata 1986: 356.

27 Valentine 1992: 39. 
olyan személyek tartoznak, akik nincsenek egymással rokoni viszonyban, viszont valamilyen érdek - például üzleti - áll fenn köztük, ezért az együttmúködés elősegítésére nagyfokú figyelmet fordítanak, és minden esetben előzékenységet (enryo 遠慮) tanúsítanak egymással szemben. Létezik egy ennél kijjebb eső kör, ahova azokat az idegeneket sorolhatjuk, akikhez semmiféle viszony nem fúzi az adott személyt, így teljes közömbösséggel, minden előzékenység nélkül viselkedhetnek velük szemben („teljesen idegen”, azaz aka no tanin 赤の他人). Soót, egyfajta negatív attitúd is megfigyelhetó: ismeretlenek révén potenciális veszélyforrásként tekintenek rájuk, ezért lehetôség szerint kerülik a velük való kontaktust. ${ }^{28}$

A távolságtartó magatartás egyik fő oka tehát az lehet, hogy a közösségen kívülról származó emberről nem áll rendelkezésre semmiféle biztos háttér-információ, ezért nem lehet tudni, hogyan fog viselkedni bizonyos szituációkban. A kiszámíthatatlanság okozta bizonytalanságérzet szignifikánsan mutatkozik meg a mai japán társadalomban is, amikor a japánok más etnikumhoz és kultúrához tartozó személlyel találják szembe magukat. Hosszú távon azonban mindkét fél, tehát a közösséghez látogató és az oda tartozó személy között is megerósödhet a kölcsönös megbizonyosodás igénye, amelynek kiindulópontja az információcsere. Amint a felek kiismerik egymást, csökken a bizonytalanság érzete, és fokozatosan a bizalom veszi át a helyét. ${ }^{29}$

Ezzel szemben a japán típusú emberi kapcsolatok legbelsô körébe a rokonok és családtagok (miuchi 身内) tartoznak, akik tehát az egyén privát szférájának szoros részét képezik. A privát szféra azonban sokszor egy sajátos, a családénál sokkal tágabb fogalmat is takarhat, hiszen gyakran használják a nakamauchi 仲間内 kifejezést, amely azokat a személyeket jelöli, akik nem családtagok, de mégis gyakran érintkeznek az adott személlyel. Ilyenek az osztálytársak vagy a saját céges kollégák (shigoto nakama 仕事仲間) is..$^{30}$

\footnotetext{
Doi 2001: 44.

29 Berger 1987: 41.

30 Yoneyama 1976: 22.
} 
Ekképpen a privát szféra nemcsak a családi fészekre, hanem a közösségteremtő erővel bíró iskolára vagy a cégre is kiterjedhet. ${ }^{31}$ Tehát az egyén magánéletét igen gyakran a nagy befolyásoló erővel bíró közösség szintjén éli, amely legalább olyan jelentőséggel bír számára, mint a saját családja vagy rokoni körei ${ }^{32} \mathrm{Az}$ európai mentalitástól eltéróen ugyanis a japán társadalom alapegységét nem az egyén, hanem a meghatározott szabályok szerint létrejött és múködő csoportok (shōshūdan 小集団) adják. A hagyományos mezőgazdasági falvak kiterjedt közösségi munkálataiban sem egyénként, hanem több tagot számláló családként (ie 家) vettek részt. ${ }^{33}$ Az egyént háttérbe szorító közösségi munkavégzés hagyománya a jelenkori társadalomban is megfigyelhető: az adott helyen, adott cél érdekében együttmúködő, kisebb munkahelyi csoportosulásokba való tartozás olyan érzelmi biztonságot jelent a tagok számára, mint amilyet saját családjuk nyújthat. ${ }^{34}$

Csakhogy akár a kapcsolatok külső, akár belső köreiről legyen is szó, az egyén számára mindig egyértelmú és releváns, hol húzódik a kettő közti határ. Lényegében a japánok a mindennapi társas kapcsolataikat ezekbe a külső-belső körökbe osztják fel, és ennek függvényében viselkednek egymással. ${ }^{35}$ Más szóval a japán típusú kommunikációnak két éle van: az egyik az a viselkedés, amit a közelálló személyeknek mutatnak, a másik az, amelyiket az ismeretleneknek, tehát a társadalom felé nyilvánítanak ki. Az ismeretlenek irányába mutatott magatartás minimális társadalmi előírást tartalmaz, míg az ismerősökhöz, családtagokhoz, magához a céghez való kötődésben hatalmas áldozatvállalási készség mutatkozik meg. ${ }^{36}$

A japán társadalmi érintkezések során elengedhetetlen, hogy a résztvevők teljes mértékben tisztában legyenek azzal, ki melyik körbe tartozik, menynyiben viselkedhetnek egymással szemben az uchi vagy a soto kimondatlan elvárásai alapján. ${ }^{37}$ Éppen ezért folyamatosan definiálniuk kell saját

\footnotetext{
Doi 2001: 40 .

Doi 2001: 42.

Nakane 2009: 23.

Nakane 2009: 24.

5 Doi 2001: 43.

36 Yoneyama 1976: 31.

37 Lebra 1976: 23.
} 
helyzetüket a másikéhoz képest, így helyezve el önmagukat a társadalmi csoportok egyes körein belül. ${ }^{38}$ Az egyén életében döntő jelentőségú a csoporthoz való tartozás lehetősége, hiszen akik kívül esnek minden ilyen közösségen, azoknak a státusza bizonytalan, sorsuk emiatt sokszor a társadalmi ellehetetlenítés és kirekesztés lesz. ${ }^{39}$

Habár az elhatárolódás egyik legszembeötlőbb formája a közömbösség kimutatása és éreztetése, japán részről valójában igen intenzív, kifelé irányuló figyelem övezi a soto körbe tartozó ismeretlen személyeket. ${ }^{40}$ A közönyösség látszatának ellenére is érdeklődnek, illetve mindig is érdeklődtek a számukra ismeretlen tudást és kultúrát képviselők iránt. A japánok saját belső világukkal (uchi) szemben tehát megkülönböztették mindazt, ami kívülről (soto) jött, csakhogy a két szféra között húzódó határ az idők folyamán mindig máshol húzódott. Például a Hokkaidón élő ainuk máig sem számítanak a japán nemzetiségi tudat belső körébe, hivatalosan nemzetiségként vannak elismerve. ${ }^{41}$ Habár az európaiak megjelenésekor is létezett az erőteljes elhatárolódási szándék, ezzel együtt felfigyeltek rájuk, és élénk kíváncsisággal fordultak a keresztény misszionáriusok felé, mint ahogy azt Xaveri Szent Ferenc is feljegyezte írásaiban. ${ }^{42}$

A japánok az uchi és soto köreibe sorolható emberi kapcsolataikat a tatemae 建前 és a honne 本音 duális struktúráján alapulva irányítják. ${ }^{43} \mathrm{~A}$ tatemae azt a nyilvánosság előtt megmutatkozó, társadalmilag elfogadott viselkedést jelöli, amely az egyén pozíciójának, illetve a társadalmi elvárásoknak egyaránt megfelel. A tatemae konvencióit a nagy létszámban történő együttélés több évszázados hagyományai alakították ki a japán szigeteken, így a közösségi kapcsolatokon keresztuil értelmezhető fogalmat takar. ${ }^{44} \mathrm{~A}$ tatemae kifejezést a házépítési munkálatokból kölcsönözték, amikor is a felső hosszgerendát legutoljára illesztették be a ház szerkezetébe, aminek sikerét

\footnotetext{
Nakane 1973: 2.

Dickie-Clark 1966: 32.

Doi 2001: 46.

Karube 2014: 4.

Doi 2001: 47.

Doi 1988: 61.

Doi 1988: 36.
} 
gyakran megünnepelték az építőmesterekkel, így erről a jelentős folyamatról nevezték el ezt a jelenséget. ${ }^{45}$ Ezzel szemben a honne az egyén valódi érzelmi megnyilvánulásait és gondolatait jelöli, amelyek gyakran ellentétesek a társadalmi elvárásokkal. Az egyéni érzéseket igyekeznek magukban tartani, és csupán a belsőséges viszonyban levő barátokkal, családtagokkal osztják meg ezeket, ezért a honne fogalma a csoportos kapcsolatokra vetítve nem értelmezhető. ${ }^{46}$ Ellenben a honne és a tatemae szerinti viselkedést a kommunikációban részt vevő minden tagnak szükséges elsajátítania ahhoz, hogy megfelelően múködjenek a társas kapcsolataik. ${ }^{47} \mathrm{~A}$ honne és a tatemae tehát csak egymással összefüggésben értelmezhetôk, és mindkettő elsajátítása nélkülözhetetlen a japánok társadalmi kommunikációjában. ${ }^{48}$

\section{A közösségi összetartás számkivetettjei}

Természetszerú, hogy a japánok nem csupán idegenekkel, hanem saját, de ismeretlen honfitársaikkal is érintkeznek. Közös mozgásterük a seken 世 間, tehát az a társadalmi tér, ahol elfogadott a nem vérrokon japánok közti mindennapos találkozás. ${ }^{49} \mathrm{~A}$ japánok többségének szemében a széles értelemben vett társadalom, ahol az ismeretlenek egymással való érintkezése, együttmúködése biztosítja a közösségi harmónia fennmaradásának lehetőségét, tiszteletre méltó fogalom, ezért használhatják a sama 様tiszteleti jelzőt utána (seken sama 世間様). ${ }^{50}$ Ez azt is jelenti, hogy a japánok igen tudatosan tekintenek saját társadalmukra, amelyben fontos szerep jut a teljesen idegen személyeknek és az általános értelemben vett közvéleménynek is. A társadalmi elvárások és a közvélemény jelentőségét hangsúlyozza még számos olyan szólásmondás is, amelyekben a seken fogalma kap szerepet. Ilyen a seken shirazu 世間を知らず (olyan személy, aki nem áll a realitások talaján)

\footnotetext{
Doi 1988: 35.

Doi 1988: 37.

Doi 1988: 61.

Doi 1988: 87.

Yoneyama 1976: 13.

Yoneyama 1976: 14.
} 
vagy a seken no kuchi ni to wa taterarenai 世間の口に戸は立てられない (,,az emberek közt gyorsan terjedő pletykát nem lehet leállítani”). Ha egy adott közösséghez tartozó személy valamilyen oknál fogva „kilóg a sorból”, akkor sokkal kirekesztőbben viselkedhet vele a közösség, mint akár egy közösségen kívülivel szemben. A közösségi tag eltérő mivolta miatt nem határozható meg pontosan a hovatartozása, így nehezen dönthető el, hogy hol húzódik a közösség és az egyén közti határ, valamint az, hogy mennyi ideig áll majd fenn ez a kérdéses állapot, ezért a periférián álló marginal menként tekintenek rájuk. ${ }^{51}$ Abban az esetben, ha a csoport és az adott személy közti határok egyértelmúnek és állandónak bizonyulnak, akkor nem csoporttagként, hanem teljes egészében kívülállóként tekintenek rájuk. Ilyen formában a homogénnek beállított japán társadalom marginal menként tekint a már említett nemzetközi házasságból szuiletett japánokra, de az ainukra vagy az okinawaiakra is. ${ }^{52}$

A japán társadalomban, amely tehát az emberi kapcsolatok külső és belső köreit is magába foglalja, létezik a „belehal a szégyenbe” tartalmú mondás, amelyet a társadalom által elfogadott normák megsértése során használnak ( $s e$ ken ni taishite kaomuke dekinai 世間に対して顔向けできない). ${ }^{53}$ Ha valaki súlyos, etikátlan cselekedetet hajt végre, például embert öl, akkor nem csak a saját, hanem a hozzátartozói fejére is bajt hoz, hiszen a társadalom egésze kirekeszti, megbélyegzi a családot, azaz büntetés gyanánt a búnös privát szféráját veszik célba. A japánok éppen emiatt igyekeznek mindenáron elkerülni a szégyenbe kerülést, hiszen ez rövid távon ellehetetleníti a közösségi életüket, ami pedig igen súlyos büntetésnek számít. ${ }^{54}$ Ez a fajta közösségi szemlélet és erős szégyenérzet a japán társadalomban mélyen gyökerező gondolat, hiszen már a hagyományos falusi közösség keretein belül elkövetett búnök, illetve a falu jó hírének szégyenbe hozása is megtorlással, kirekesztéssel járt, amelynek büntető jellegét a mura hachibu 村八分 kifejezéssel illetik..$^{55}$

\footnotetext{
Dickie-Clark 1966: 48.

52 Dickie Clark 1966: 40.

53 Yoneyama 1976: 28.

54 Yoneyama 1976: 28.

55 Yoneyama 1976: 29.
} 
Ez azt is jelenti, hogy a japán falusi közösség összetartozás-érzete is igen erós lehetett, hiszen a közösség minden tagja kivétel nélkül közrejátszott a falu fennmaradásáért zajló küzdelemben, az együtt végzett termelői és a közösségi munkákban, valamint a közös ünnepekben is. Ez az egymásra utaltság és sorsközösségi érzet azt eredményezte, hogy mindattól, ami a falun kívülről érkezett, vagy a saját köreiken belül veszélyt jelentett a közösségre nézve, igyekeztek elzárkózni. A külvilágtól való függetlenedés reményében próbáltak saját magukra hagyatkozni, önellátóak lenni. ${ }^{56} \mathrm{~A}$ falusi közösség együttélésének íratlan szabályai ősi időkre nyúlnak vissza, tehát a régi hagyományok alapján rögzült életmódbeli és rituális szokásokat követtek, így nem meglepó, hogy a falusiak számára a közösséghez tartozás egyet jelentett a világban való létezés érzetével. A falut alkotó egyének élete szorosan kötődött a közösséghez, meghatározta életük, sôtt haláluk minden fontosabb részletét, ezért születésük pillanatától kezdve szoros társadalmi szimbiózis jellemezte életüket. Pontosabban, már a születése előtti időszakban is megfigyelhetô volt a leendő közösségi tag felé irányuló kitúntetett figyelem. ${ }^{57}$ Például az egyik újévi rítus gyanánt a falusi gyermekek ellátogattak az újházas párok házához, ahol „megseprúzték” a fiatalasszonyt (yometataki ヨメ夕タキ), hogy így segítsék elő a közösség létére nézve is fontos teherbeesés folyamatát. ${ }^{58}$

56 Araki 1973: 30.

57 Papp 2016: 87-102.

58 Araki 1973: 31-32. 


\section{A japán típusú befogadás és kirekesztés modelljének ambivalenciája}

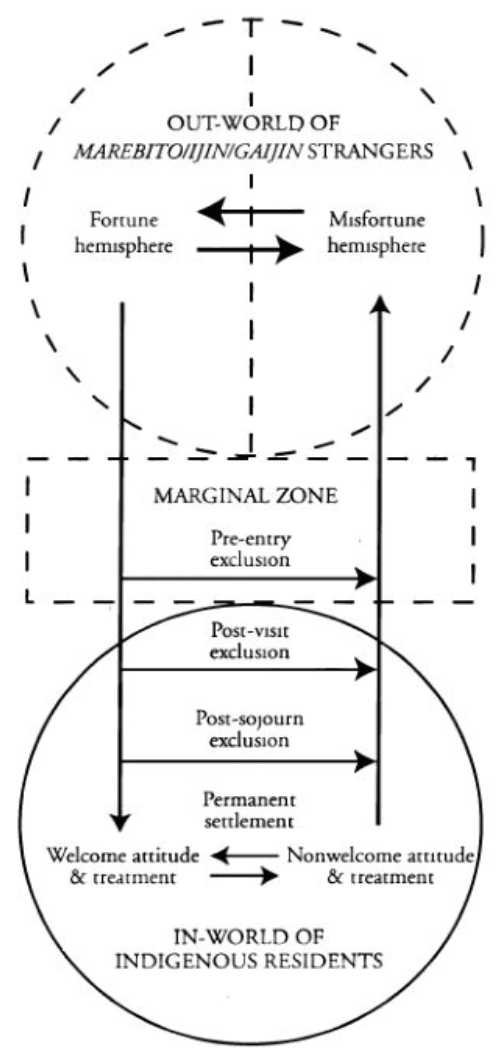

1. ábra A japán típusú befogadás és kirekesztés rítusának modellje. Forrás: Ishii 2001: 160.

A japán közösségbe való befogadás, illetve az onnan való kirekesztés folyamata térben és időben látványosan megragadható (1. ábra). Ennek térbeli ábrázolásában Ishii (2001) két körre osztva különíti el a külvilágból érkezettek (marebito, ijin, gaijin) és az őslakosok belső világát. A külvilág egy olyan, a valóságon vagy képzeleten alapuló, meghatározhatatlan tér, ahol az idegenek élnek. A szaggatott vonallal azt igyekszik kifejezni, hogy nem egyértelmú, hol húzódnak annak határvonalai ${ }^{59}$ A külső szféra körét belülről egy

59 Ishii 2001: 160. 
újabb szaggatott vonallal is elválasztja, amelyen belül az egyik részbe a szerencsét hozó idegenek kerültek. Ők azok, akik jólétet és boldogságot hoznak magukkal, valamint különféle híreket a külvilágból. Velük szemben vannak a másik oldalon a szerencsétlenséget hozók, akik a pusztulás, a boldogtalanság és a szenvedés hírnökei. Az idegenek két csoportja között azonban nagyon könnyú az átjárás: a hiedelmek szerint az egyik pillanatban a pozitív értékeket képviselő idegen a másik pillanatban a közösség vesztére törhet. ${ }^{60}$

Manapság a globalizáció hatására a Japánba érkező külföldiek minősülnek ijineknek, akik ilyen módon látogatást tesznek az őslakosok világába. A belső szférába való belépéshez szükséges a határzónán való áthaladás, hiszen ez a tér választja el, illetve kapcsolja össze az idegenek és a japánok világát. Ez a képzeletbeli határzóna már az ősi időktől fogva létezett a japán közösségi tudatban, hiszen a piacnapokon, vásárokon itt találkoztak az ijinekkel, akik nem tehették be lábukat a falu területén belülre. A mai értelemben vett határzónának a repterek és kikötők felelnek meg, ahol hasonló találkozás történik a külföldi és japán állampolgárok között. Ezzel szemben, ha megfigyeljük az őslakosok világát, akkor határozott körívú, azaz egy zárt és belső egységet alkotó világ képzete mutatkozik meg, amely a közösségi tagok szocializációjának fontos színtere. A belső szféra határpontjaival tisztában vannak az ott élók, akik az adott helyzettől függóen hol pozitív, hol pedig negatív fogadtatásban részesítik az oda érkezóket. ${ }^{61}$

A hagyományos falusi társadalmakban az idegenek három lépésben juthattak be a faluba. Az első a belépés elótti szakasz, amikor is a határzónában vizsgálaton estek keresztül: egy mágikus erővel bíró személy döntötte el, hogy veszélyt jelentenek-e a közösségre nézve. Csak az juthatott tovább, akit veszélytelennek, valamint szerencsés erókkel bírónak ítéltek, akik nem feleltek meg, azokat elúzték. A második szakaszban megtörténik a belépés, amikor is az ijineket szívélyesen fogadják és üdvözlik, valamint vendégül látják a faluban, amelyre így jó szerencsét és áldást hoznak. Abban az esetben, ha az ijinek ott tartózkodása során valamilyen tragédia (éhínség, haláleset,

\footnotetext{
60 Ishii 2001: 161.

61 Ishii 2001: $162-163$.
} 
járvány) következett be, akkor az ijineket gyanúsították meg vele, ezért rögtön kirekesztés lett a sorsuk: számúzték, vagy rosszabb esetben elpusztították ôket. Így nem meglepó, hogy a közösség hozzáállása is nagyon változékony lehetett, akármikor átcsaphatott a másik végletbe. Lényegében az országba látogató külföldiekkel szemben is hasonló elvárások nyilvánulnak meg: az általuk képviselt technológia, hírek, értékek mind jólétet hozhatnak az országnak, de ha a vendéglátó fél elvárásainak valamilyen módon nem tesznek eleget, akkor kirekesztik óket a társadalomból. Ekképpen, ha a falusi közösség megbizonyosodott az idegenek pozitív képességeiről, akkor lehetővé tették számukra, hogy hosszabb idôt töltsenek a belsô szféra keretei között, akár engedélyezett munkavégzés mellett, bár még ez idő alatt is feszült figyelem övezte őket. Sőt a későbbiek során bármikor megvádolhatták őket egy szerencsétlen eseményből kifolyólag, ami gyakran okozhatta a vesztüket. ${ }^{62}$

Ilyen módon a Japánba költözött és letelepült életmódot folytató külföldiek helyzete is ehhez hasonló. Ugyan tökéletesen elsajátították a japán kultúrát és nyelvet, de nehezen válhatnak a közösség teljes értékú tagjává, hiszen sajátos kinézetük felhívja a figyelmet arra, hogy eltérő szociokulturális környezetből származnak. ${ }^{63}$ Ugyanakkor nem csupán a kinézet okozhat hasonló problémát: a külföldi (pl. brazil, argentin, fülöp-szigeteki) diaszpórákban élő, második generációs japán kivándorlók és gyermekeik (nikkei-jin 日 系人), akik munkavállalási céllal hosszabb-rövidebb időre visszatérnek az anyaországba, sokszor nehézségek közepette, „megbélyegzett idegenként” próbálnak beilleszkedni - gyakran sikertelenül - a közösségbe.

Habár a nikkei-jinek az 1990-es évektól kezdve egyre nagyobb számban jelentek meg a munkaerópiacon, ${ }^{64}$ köztük elsősorban a második és harmadik generációs leszármazottak esetében adódtak problémák, ugyanis az identitásukat és kultúrájukat tekintve nem Japánhoz, hanem a saját külföldi diaszpórájukhoz kötődtek. ${ }^{65}$ Emiatt, illetve hiányos japán nyelvtudásuk miatt

\footnotetext{
Ishii 2001: 163 .

63 Ishii 2001: 164.

64 1993-ban 200000 fő nikkei-jin származású munkavállaló volt Japánban (forrás: Kajita 1995: $11)$.

65 Kajita 1995: 12.
} 
is „félig japán idegenként”, ambivalens módon tekint rájuk az anyaország. A japán felmenőkkel rendelkezó, de a kultúra és a nemzeti identitás terén idegennek számító nikkei-jinek hovatartozása mindmáig számos megválaszolatlan kérdés elé állítja a japán társadalmat, amely kezdetben drámai jelenségként élte meg a japán kinézetű „idegen” bevándorlók beáramlását az országba. A nikkei-jinek megjelenésével elhomályosult az a határvonal, amellyel megállapítható lenne, hogy ki és milyen értelemben számít japán identitású személynek, ezzel pedig megkérdőjelezhetővé vált a nemzeti hovatartozás kérdése is. ${ }^{66}$

A terjeszkedő külgazdasággal párhuzamosan, az 1970-es évek elejétől kezdve külön névvel kezdték illetni azokat a gyermekeket, akik a családfenntartó apa munkája miatt legalább három hónapot töltöttek külföldön. Ök a kikokushijók 帰国子女, akik gyakran váltak az iskolai bántalmazások áldozatává, főként, ha huzamosabb ideig éltek távol, mivel hazatérésük után nehezen tudtak azonosulni az uniformizált japán oktatási rendszerrel és társadalommal. A nehezen alkalmazkodó személy „mentális betegségének” (futekiōbyō 不適応病) fogalma is a kikokushijók problémásnak tartott viselkedése kapcsán terjedt el a köznyelvben. Társadalmi megítélésük szintén ambivalens, hiszen a kikokushijók sokszor hiányos japán nyelvi készségei és a közösség rendjét fenyegető viselkedészavarai miatt gyakran „,idegen japánként" tekintenek rájuk. A társadalomba való mielőbbi visszaszoktatásuk és rehabilitációjuk céljából a japán kormány több oktatási intézményt is létrehozott, így segítve a hazatértek mielóbbi asszimilációját. ${ }^{67}$

A japánok tehát a globalizáció közepette is megőrizték azt az idegenek, tehát a nem japán kinézetú külföldiek és a saját közösségükből kilógó elemek felé irányuló ambivalens, a befogadáson és kirekesztésen alapuló mechanizmust, amely a mai napig kimutatható a társadalmi kommunikációjukban, és amely fontos szerepet játszik saját identitásuk és nemzeti hovatartozásuk meghatározásában.

\footnotetext{
66 Kajita 1995: 13.

67 Goodman 1990: 164-166.
} 


\section{Összefoglalás}

Egy kívülálló számára nehéznek bizonyulhat a japán közösség zárt világába való bejutás: az első találkozás alkalmával a világok közti térben utazó, határ menti személyként (marginal man) tekintenek rá, akit az ősi idókben a marebito, majd a késóbbiekben az ijin és a gaikoku-jin elnevezéssel illettek, és akiket a közösség felfogásának megfelelóen hol pozitív, hol pedig negatív fogadtatásban részesítettek. Az idegenek alakjának és szerepének megítélése meglehetősen ambivalens, amelynek gondolatvilága mindmáig mélyen gyökerezik a japán társadalomban. Csakhogy éppen ez az ambivalens látásmód teszi lehetővé, hogy a közösség szabályait követve átmenetileg, vagy szerencsés esetben a tisztátalanság (kegare) elhárítása miatt szükséges rítusok elvégzése után véglegesen lehetôvé tegyék az idegenek bejutását a csoportba. Ugyanakkor, ha bebizonyosodik róluk, hogy a közösség létét fenyegető veszélyt rejtenek magukban, akkor az idegenek sorsa a végleges kiközösítés lesz.

Az idegenekkel kapcsolatos, ellentmondásokon alapuló nézetek azonban manapság is erősen kihatnak a japánok mindennapi életére és identitásbeli gondolkodásmódjára. A társadalmi problémaként számon tartott nikkei-jineket vagy kikokushijókat, akik hosszabb idô után tértek vissza az anyaországba, vagy a Japánban élő, de nemzetközi házasságból születetteket is félig japán származású ,idegennek” tekintik és megbélyegzik. Ezek a japán származású, de eltéró identitású családokból származó emberek nagy veszélyt jelentenek a társadalom egészére, ugyanis jelenlétükkel megkérdőjelezhetôvé és bizonytalanná teszik a japán és nem japán nemzetiségúek között húzódó határvonal pontos helyét.

Azonban nemcsak az „idegennek” tartott személyek, hanem az óslakos japánok életét is befolyásolják a merev közösségi és társadalmi szabályok, amelyek nagy hatással vannak a privát szférára. Megkövetelik, hogy az egyén a közösségi konvenciók és elvárások, a tatemae elve alapján viselkedjen, és hogy képes legyen a társas kapcsolatainak belsố és külső körei között különbséget tenni, hiszen ez a sikeres társadalmi kommunikáció legfontosabb elófeltétele. Azokat a japánokat, akik valamilyen formában vétket követnek 
el a közösséggel szemben, szintén megbélyegzik, amivel ellehetetlenítik a társas kapcsolataikat, ez pedig súlyos büntetést jelent a számkivetettek számára.

A közösségi érintkezések és az identitás kérdésének tükrében érdekes kérdéseket vet fel a továbbiakban, hogy a külföldön munkát vállaló japánok hogyan tekintenek magukra és az ottani idegenekre az új társadalmi közegben, miként képesek felépíteni itt saját közösségüket, valamint azt, hogy milyen módon igyekeznek megőrizni nemzetiségi tudatukat és a Japánból magukkal hozott konvenciókat, elvárásokat.

\section{Másodlagos szakirodalom}

Akamatsu Keisuke 赤松啓介 2005. Sabetsu no monzoku gaku 差別の民俗 学 [A diszkrimináció néprajza]. Tokió: Chikuma shobō.

Akasaka Norio 赤坂 憲雄 1992. Ijinron josetu 異人論序説 [Bevezetés az idegen-elméletbe]. Tokió: Chikuma shobō.

Araki Hiroyuki 荒木 博之 1973. Nihonjin no kōdō yōshiki 日本人の行動椂 式 [A japánok viselkedési formái]. Tokió: Kōdansha.

Berger, Charles 1987. „Communicating under uncertanity.” In: M. Rolaff (ed.) Interpersonal Processes, Newbury Park. CA: Saga, 39-62.

Dickie-Clark, H.F. 1966. The Marginal Situation. London: Routledge and Kegan Paul.

Doi, Takeo 1988. The Anatomy of Self: The Individual Versus Society. Tokyo: Kodansha International.

Doi, Takeo 2001. The Anatomy of Dependence. Tokyo: Kodansha International. 
Goodman, Roger 1990. „Deconstructing an anthropological text: a 'moving' account of returnee schoolchildren in contemporary Japan." In: Eyal Ben-Ari - Brian Moeran - James Valentine (eds.) Unwrapping Japan: society and culture in anthropological perspective. Honolulu: University of Hawaii Press, 163-187.

Hamabata, Matthews Masayuki 1986. „Ethnographic boundaries: culture, class and sexuality in Tokyo." Qualitative Sociology 9.4: 354-371.

Ishii, Satoshi 2001. „The Japanese Welcome-Nonwelcome Ambivalence Syndrome toward Marebito/ Ijin/ Gaijin Strangers: Its Implications for Intercultural Communication Research.” Japan Review 13: 145-170.

Komatsu Kazuhiko 小松和彦 1995. Ijinron: minzoku shakai no shinsei. 異人論：民俗社会の心性 [Idegen-elmélet: a népi társadalom természete]. Tokió: Chikuma shobō.

Lebra, Takie Sugiyama 1976. Japanese Patterns of Behavior. Honolulu: University of Hawaii Press.

Kajita, Takamichi 1995. „Characteristics of the Foreign Worker Problem in Japan: To an Analytical Viewpoint." Hitotsubashi Journal of Social Studies 27. 1: 1-26.

Karube Tadashi 苅部 直 2014. „Uchi to soto no shisō shi $\ulcorner$ 内と「外」 の思想史 [A „kint” és a „bent” fogalompárjának eszmetörténete]”. In: Karube Tadashi 苅部直 - Kurozumi Makoto 黒住真 (eds.) Nihon no shisōshi dai 3 kan: uchi to soto = taigaikan to jikozō no keisei 日本 の思想史第3巻: 内と外=対外観と自己像の形成. Tokió: Iwanami shoten.

Miyamoto Tsuneichi 宮本 常一 1969. „Hōrōsha no keifu 放浪者の系譜 [A vándorlók leszármazása]”. Dentō to gendai 伝統と現代 2.3: 13-23. 
Miyata Noboru 宮田登 1986. „Teichakumin kara no shiten wo koete 定着民 からの視点を超えて [A letelepültek nézőpontjának meghaladása]”. Shūkan dokusho-jin 週刊読書人 5.5: 1 .

Nakane, Chie 1973. Japanese Society. Harmondsworth: Penguin.

Nakane Chie 中根 千枝 2009. Tate shakai no rikigaku 夕テ社会の力学 [A vertikális társadalom mechanizmusa]. Tokió: Kōdansha.

Namihira Emiko 波本 恵美子 2009. Kegare ケガレ [Tisztátalanság]. Tokió: Kōdansha.

Nippon Kokugo Daijiten 9. 日本国語大辞典 9. [Japán nyelvi nagyszótár 9.] 1987. Nihon Daijiten Hakkōkai 日本大辞典刊行会 (ed.) Tokió: Shōgakukan.

Papp Melinda 2013. „A korai gyermekkor rítusai Japánban és a hozzákapcsolódó hagyományos népi hitvilág." Távol-keleti Tanulmányok 3.1-2: 227-248.

Papp, Melinda 2016. Shichigosan. Change and Continuity of a Family Ritual in Contemporary Urban Japan. New York: Palgrave Macmillan.

Park, Robert Ezra 1928. „Human migration and the marginal man.” American Journal of Sociology 33: 881-893.

Perkins, Dorothy 1991. Encylopedia of Japan: Japanese History and Culture, From Abacus to Zori. New York and Oxford: Facts on File.

Simmel, Georg 1950. „The stranger.” In: Wolff Kurt (ed.) The Sociology of Georg Simmel. New York: Free Press, 402-408.

Valentine, James 1992. „On the borderlines: the significance of marginality in Japanese society." In: Eyal Ben-Ari - Brian Moeran - James Valentine (eds.) Unwrapping Japan: society and culture in anthropological perspective. Honolulu: University of Hawaii Press, 36-57.

Yoneyama Toshinao 米山 俊直 1976. Nihonjin no nakama ishiki 日本人の 仲間意識 [A japánok társasági tudatossága]. Tokió: Kōdansha. 